\title{
STUDIES ON SEED-SETTING IN LEGUMINOUS PLANTS. II. VETCHES
}

\author{
Rolf ManNeR \\ Plant Breeding Institute Gullåker, Hammenhög, Sweden
}

Received April 28, 1958

With vetch in the present investigation is understood Spring-Vetch or Common vetch (Vicia sativa $\mathrm{L}$.) $(4,10,15)$.

The systematics and the characters of different species and different "types» are extensively given by Muratova (18) and Tupikova (23). An extensive karyological study is undertaken by Sveshnikova (22). Karyological analysis of some species of Vicia inter alia Vicia sativa has been carried out by Coutinho (3).

Tupikova (23) considered the number of flowers in inflorescence to be a strictly" heritable character and, inter alia, size of seed, size of pod to be "varietal or racial characters slightly fluctuating under the influence of external conditions».

Common vetch is as the pea a self-pollinated and -fertilized plant $(2,13,14,26)$.

According to HeGI (8) the flowers are single or in pairs in the upper axils. The peduncles are very short.

The influence of the climate on the vetch crop has been pointed out, $(21,26)$. VALLE (24) was however of the opinion that vetch is a more certain crop than peas.

The difficulty of getting seed yield of vetch in Finland is considered by SAULI (20) to depend on the late ripening of the plant. The growing of vetches in mixture with oats is extensively investigated by HäNNINEN $(11,12)$.

The main stem of vetch soon stops its development and side-branches develop from the base according to CLARK and Malte (2).

The seed size is a heritable character according to MüLLER (19). The same author considers the seed-setting in the pods to be a character which must be taken into consideration in selecting vetches. He also considers that no correlation exists between seed size and green yield.

MÜLLER (19) considers that no correlation exists between high number of seeds per pod and green yield, but is of the opinion that in moist years when the plants grow very large the seeds ripen very late and the seed-setting is poor. 
FouRY (7) has given examples of differences in chemical composition between different origins of vetches. The same author has further given an extensive list of literature concerning the vetches. The present author will not repeat this list here, but merely refer to it.

\section{Materials and methods.}

The present study was conducted during the years 1956-58 at Gullåkers Plant Breeding Institute, Hammenhög, Sweden. The work was carried out in connection with the practical plant-breeding work there.

The material used for the present investigation was as follows:

I. Svalöfs söt, Stjärn, $\mathrm{Hg}$ 8042, Svalöfs söt $\times$ Stjärn $\left(\mathrm{F}_{2}\right)$, Svalöfs söt $\times \mathrm{Hg} 8042\left(\mathrm{~F}_{2}\right)$. Altogether 370 plants were investigated as to the following characters inter alia:

1. Number of flowers per plant.

2. Number of developed pods per plant.

3. Percentage of non-developed pods.

4. Number of node with the lowest pod, on an average.

5. Number of node with the highest pod, on an average.

6. The pod-bearing part of the plant, measured in nodes.

7. Plant height in centimetres.

8. The pod frequency on different nodes.

9. The frequency of flowers not forming pods and fallen pods.

10. Mean number of seeds per plant.

11. Mean seed weight per plant.

12. Mean seed weight.

13. Mean thickness of the stem.

14. Mean length of the pods.

15. Mean breadth of the pods.

16. Mean length of the internodes.

17. Mean seed weight of seeds with different positions in the pod.

18. Pod-setting percentage.

19. Flower frequency on different node number.

20. Pod frequency on different node number.

21. Percentage of fully developed seeds.

II. Svalöfs söt $\times$ Stjärn $\left(\mathrm{F}_{2}\right)$ altogether 20 plants of this cross were investigated as to the following characters inter alia:

22. Percentage and number of fully developed seeds.

23. Percentage and number of defective seeds and dead ovules.

24. Mean seed weight.

25. Pods with all seeds fully developed.

26. Length of pods, millimetres.

27. Breadth of pods, millimetres.

28. Number of ovules per ovary.

29. Seed weight in milligrams per pod.

30. Differences between different materials.

31. Influence of number of pods per plant.

From each plot ten plants were analysed. The crossings were performed in 1954 between lines from the varieties mentioned above. All these populations are held 
separate and from each of them (= plot) ten plants are taken. Thus the numerical material for the minimum and maximum values are means for ten plants.

Tables $1,3,5$ and 6 are based on material group I. The other tables are based on material group II.

The seed yield of vetches is per hectare $=$ number of plants $\times$ mean seed weight per plant. Mean seed weight per plant $=$ number of pods per plant $\times$ number of seeds per pod $\times$ mean seed weight. This is consistent with the formulas given by Wellensiek (25) for peas, Heuser (9) and Broekema (1) for cereals, and Manner (16) concerning flax.

With defective seeds are understood such as have been estimated to be less than half the normal for fully developed seeds of the variety or the cross in question, and have shown signs of defective development or defective ripeness, thus fully in accordance with the methodics used for the classification of the seeds of peas (17). "Ovules that not have given rise to seeds have been mentioned as 'dead ovules' or sometimes 'non-developed seeds'. The flowers that have not given rise to pods containing any seed at all are called 'non-developed or fallen pods'. This terminology is used since it is not quite clear what has happened with these flowers, ovaries or pods" (17). As to vetch it was very difficult to determine the number of defective seeds and dead ovules, because all stages of seed development were found, which the present author considered to depend on inter alia defective ripening of the seeds in the highest pods.

Minimum and maximum values given in Table 1 are calculated on ten plants from each plot. The plants are chosen from the plots at random. Consideration is only paid to the largest of the branches.

The $\chi^{2}$-values have been calculated in conformity with FinNey (5) and the significance has been estimated in accordance with FisheR and YATES (6) and were denoted by asterisks as follows: $* * *=\mathrm{P} \sum 0.001$ (highly significant), $* *=\mathrm{P} \overline{\varnothing 0.01}$ but $>0.001$ (satisfactorily significant), and ${ }^{*}=\mathrm{P} \sum 0.05$, but $>0.01$ (significant).

\section{Mean performance and breadth of variation}

The number of flowers per plant was on an average 9.1 and the corresponding number of developed pods per plant was 7.1. Both these mean numbers were smaller than that obtained for peas. The number of flowers varied between 6.1 and 15.9. The corresponding extreme values found for the number of developed pods per plant were 4.5 and 14.3 (Table 1). From this table it further appears that the percentage of non-developed pods was much higher than for peas. The percentage mentioned varied between 2 and 64 and was on an average 21, whereas the corresponding percentage in the earlier treated material-of peas was only 5.5. This clearly indicates that the pod-setting in this material of vetches was much more defective than the pod-setting in a corresponding material of peas (17).

The first pod was on an average found on node number 6 or 7 , but a rather large variation was found, namely, between on an average 4.7 and 9.1. The corresponding extreme values for the node with the highest pod were 8.9 and 15.3. The mean height - measured in nodes - for the highest pod was 12.4, which shows that the highest 
Table 1. Mean performance and breadth of variation between different genetical materials for the investigated characters in material group I of vetches.

\section{Character}

Minimum

Mean

Maximum

Number of flowers per plant

Number of developed pods per plant

Percentage of non-developed pods

Number of node with the lowest pod

Number of node with the highest pod

The pod-bearing part of the plant measured in nodes

Plant height in centimetres

Mean number of seeds per plant

Mean seed weight per plant, grams

Mean seed weight, milligrams

Mean thickness of the stem

Mean length of the pods, millimetres

Mean breadth of the pods, millimetres

Mean length of the internodes, centimetres

$\begin{array}{ccc}6.1 & 9.1 & 15.9 \\ 4.5 & 7.1 & 14.3 \\ 2 & 21 & 64 \\ 4.7 & 6.5 & 9.1 \\ 8.9 & 12.4 & 15.3 \\ 4.3 & 7.1 & 9.7 \\ 84 & 117 & 139 \\ 32.0 & 53.6 & 116.2 \\ 1.95 & 3.97 & 7.02 \\ 54 & 74 & 94 \\ 2.0 & 2.7 & 3.5 \\ 55 & 60 & 67 \\ 7.4 & 8.7 & 10.2 \\ 8.2 & 9.4 & 11.1\end{array}$

pod was found on the 12th or 13th node on an average. The pod-bearing part of the plant - measured in nodes - varied between 4.3 and 9.7 and was on an average 7.1 nodes. In comparison with the results obtained for peas all the numbers were somewhat larger for the vetches. It is of special interest to see that on an average the number of pod-bearing nodes was one node larger in the vetch material than in the pea material.

Mean number of seeds per plant varied between 32.0 and 116.2 and was on an average 53.6, which is about the same as was obtained in the pea material. However, the other character largely influencing the seed yield per plant - mean seed weight per plant -- was naturally much smaller than for peas and reached on an average only the fourth part of the weights for the materials of the peas or 74 milligrams with variation between 54 and 94 milligrams.

The thickness of the stem varied between 2.0 and 3.5 millimetres and was on an average 2.7 , which is nearly half the thickness for the investigated pea material. The length of the internodes varied between 8.2 and 11.1 centimetres and was on an average 9.4 centimetres, which is about twenty per cent smaller than obtained in the material of peas (Table 1).

\section{Seed development in different parts of the pods of vetches}

In the case of the peas the percentage of defective and non-developed seeds was smallest for the central seeds in the pods and largest for the first seeds (ovules) in the pods. The investigation is undertaken in accordance with the corresponding investigation as to peas (17). These results agree rather well with the results obtained. for vetches. 
Table 2. Development of first, central and last seeds in the pods.

\begin{tabular}{lccccc}
\hline $\begin{array}{c}\text { Position of } \\
\text { the seed }\end{array}$ & $\mathrm{n}$ & Fully developed & $\begin{array}{c}\text { Dead ovules and } \\
\text { defective seeds } \\
\text { Number }\end{array}$ \\
\hline First & 187 & 130 & 70 & 57 & 30 \\
Central & 273 & 230 & 84 & 43 & 16 \\
Last & 187 & 154 & 82 & 33 & 18
\end{tabular}

Of the first ovules in the pods 70 per cent developed to fully developed seeds whereas 30 per cent gave defective seeds and dead ovules. The corresponding percentages for the central ovules were 84 and 16 (Table 2). This shows that the percenage of defective seeds and dead ovules was about double for the first ovules in comparison with the central ovules. The differences between central and last seeds in the pods were not large. The corresponding difference was also not highly significant in the pea material. The difference between fully developed seeds on the one hand and defective seeds and dead ovules on the other was higly significant $\left(\chi^{2}=15.4^{* * *}\right)$ in the present vetch material. Further a large material containing 573 pods was investigated. The results of this investigation are given in Table 3 . The material is divided after the number of ovules in the ovaries in four groups. The results are given on the one hand for developed and defective seeds and on the other hand for dead ovules. The table shows clearly that the number and percentage, respectively, of dead ovules are clearly larger in the ends of the pods, but the differences in seed development depending on the position of the ovule in the ovary is possibly smaller in the pods whose ovaries contained the highest number of ovules. If consideration is paid only to first, central and last ovule in every pod the numbers are as follows:

\begin{tabular}{lcccc}
\hline Ovule & $\mathrm{n}$ & $\begin{array}{c}\text { Developed and } \\
\text { defective }\end{array}$ & Dead ovules & $\begin{array}{c}\text { Percentage of } \\
\text { ovules developed }\end{array}$ \\
\hline First & 573 & 506 & 67 & 88.3 \\
Central & 856 & 841 & 15 & 98.2 \\
Last & 573 & 522 & 51 & 91.1
\end{tabular}

This numerical material shows very clearly that the number of dead ovules has been much more frequent for the first and the last ovules in the ovaries, which is in full accordance with the results obtained in the peas. The difference between first and central ovule as to on the one hand developed and defective seeds and on the other hand to dead ovules was highly significant $\left(\chi^{2}=62.2^{* * *}\right)$, which was also the case for the difference between central and last ovules $\left(\chi^{2}=38.6^{* * *}\right)$.

On the whole a tendency to higher mean seed weights for pods with many seeds in comparison with pods with a smaller number of seeds per pod is found. The result agrees very well with the results obtained for the peas (17). 
Table 3. The occurrence of dead ovules and its dependence on the position in the pods.

\begin{tabular}{|c|c|c|c|c|}
\hline \multirow{2}{*}{$\begin{array}{l}\text { Number of } \\
\text { ovules } \\
\text { per ovary }\end{array}$} & \multirow{2}{*}{$\begin{array}{l}\text { Ordinal } \\
\text { number } \\
\text { in the pod }\end{array}$} & \multicolumn{2}{|c|}{ Number of } & \multirow{2}{*}{$\begin{array}{l}\text { Percentage } \\
\text { of the ovules } \\
\text { developed }\end{array}$} \\
\hline & & $\begin{array}{l}\text { developed and } \\
\text { defective seeds }\end{array}$ & $\begin{array}{l}\text { dead } \\
\text { ovules }\end{array}$ & \\
\hline \multirow[t]{7}{*}{7} & 1 & 59 & 10 & 85 \\
\hline & 2 & 68 & 1 & 99 \\
\hline & 3 & 68 & 1 & 99 \\
\hline & 4 & 69 & - & 100 \\
\hline & 5 & 68 & 1 & 99 \\
\hline & 6 & 63 & 6 & 91 \\
\hline & 7 & 63 & 6 & 91 \\
\hline \multirow[t]{8}{*}{8} & 1 & 178 & 24 & 88 \\
\hline & 2 & 188 & 14 & 93 \\
\hline & 3 & 200 & 2 & 99 \\
\hline & 4 & 197 & 5 & 98 \\
\hline & 5 & 198 & 4 & 98 \\
\hline & 6 & 192 & 10 & 95 \\
\hline & 7 & 193 & 9 & 94 \\
\hline & 8 & 181 & 21 & 90 \\
\hline \multirow[t]{9}{*}{9} & 1 & 192 & 29 & 87 \\
\hline & 2 & 210 & 11 & 95 \\
\hline & 3 & 212 & 9 & 96 \\
\hline & 4 & 212 & 9 & 96 \\
\hline & 5 & 220 & 1 & 100 \\
\hline & 6 & 208 & 13 & 94 \\
\hline & 7 & 217 & 4 & 98 \\
\hline & 8 & 213 & 8 & 96 \\
\hline & 9 & 203 & 18 & 92 \\
\hline \multirow[t]{10}{*}{10} & 1 & 77 & 4 & 95 \\
\hline & 2 & 78 & 3 & 96 \\
\hline & 3 & 79 & 2 & 98 \\
\hline & 4 & 81 & - & 100 \\
\hline & 5 & 79 & 2 & 98 \\
\hline & 6 & 78 & 3 & 96 \\
\hline & 7 & 79 & 2 & 98 \\
\hline & 8 & 79 & 2 & 98 \\
\hline & 9 & 77 & 4 & 95 \\
\hline & 10 & 75 & 6 & 93 \\
\hline
\end{tabular}

Seed development in pods and its dependence on the number of ovules per ovary

In Table 4 the results are given of a material analysed as to the development of the seeds. In this material it was found that only one pod out of six contained only fully developed seeds in the group developed from ovaries containing six ovules per 
ovary. The corresponding numbers for the pod group developed from ovaries with seven ovules per ovary were six out of twenty-three, for the group with eight, eleven out of thirty-five, for the group with nine, forty-eight out of eighty-two and for the group with ten, twenty-six out of thirty-eight. This clearly shows an increasing percentage of pods with all seeds fully developed with increasing number of ovules per ovary. The largest part of the not fully developed seeds have been defective seeds. The results obtained are in full agreement with the correspending results obtained for the peas.

As has been earlier shown in Table 3 a clearly decreasing frequency of dead ovules can however be observed. If no regard is paid to the position in ovaries and pods, respectively, the percentages of defective and non-developed seeds in the present material are as follows:

\begin{tabular}{cccccr}
\hline $\begin{array}{c}\text { Number of ovules } \\
\text { per flower }\end{array}$ & $\mathrm{n}$ & \multicolumn{2}{c}{$\begin{array}{c}\text { Defective seeds } \\
\text { number }\end{array}$} & $\%$ & \multicolumn{2}{c}{$\begin{array}{c}\text { Dead ovules } \\
\text { number }\end{array}$} \\
\hline & & & & & \\
\hline 6 & 36 & 4 & 11.1 & 6 & 16.7 \\
7 & 161 & 59 & 36.6 & 8 & 5.0 \\
8 & 280 & 55 & 19.7 & 4 & 1.4 \\
9 & 738 & 98 & 13.3 & 5 & 0.7 \\
10 & 380 & 39 & 10.3 & 0 & 0.0
\end{tabular}

The above numbers clearly indicate a decreasing number of defective seeds and dead ovules with an increasing number of ovules per ovary in the corresponding flowers. An exception is the percentage of defective seeds developed in pods from ovaries with only six ovules per ovary, but this exception must be considered to depend on the small material for this group.

\section{Seed-setting and its dependence on node number}

In Table 5 the results are given of the investigation as to the pod-setting on different nodes. From this table it clearly appears that the pod-setting percentage is much higher on the low nodes than on the high nodes. This is in full agreement

Table 4. Number of pods containing defective seeds or dead ovules.

\begin{tabular}{|c|c|c|c|c|c|c|}
\hline \multirow{2}{*}{$\begin{array}{c}\text { Number of } \\
\text { ovules } \\
\text { per ovary }\end{array}$} & \multicolumn{2}{|c|}{ Defective } & \multicolumn{2}{|c|}{ Dead ovules } & $\begin{array}{l}\text { Defective seeds } \\
\text { and dead ovules }\end{array}$ & $\begin{array}{l}\text { Pods with all seeds } \\
\text { fully developed }\end{array}$ \\
\hline & Number & $\%$ & Number & $\%$ & Number & Number $\quad \%$ \\
\hline
\end{tabular}

$\begin{array}{rrrrrrrrr}6 & 2 & 33 & 2 & 33 & 1 & 17 & 1 & 17 \\ 7 & 12 & 52 & 3 & 13 & 2 & 9 & 6 & 26 \\ 8 & 19 & 54 & 3 & 9 & 2 & 6 & 11 & 31 \\ 9 & 30 & 37 & 3 & 4 & 1 & 1 & 48 & 58 \\ 10 & 12 & 32 & - & - & - & - & 26 & 68\end{array}$


Table 5. Pod-setting percentage in vetches.

\begin{tabular}{rrrr}
\hline Node number & $\begin{array}{c}\text { Number } \\
\text { of flowers }\end{array}$ & $\begin{array}{c}\text { Number } \\
\text { of pods }\end{array}$ & $\begin{array}{c}\text { Pod-setting } \\
\text { percentage }\end{array}$ \\
\hline 3 & 37 & 34 & 92 \\
4 & 90 & 77 & 86 \\
5 & 204 & 184 & 90 \\
6 & 282 & 264 & 94 \\
7 & 355 & 329 & 93 \\
8 & 362 & 304 & 84 \\
9 & 339 & 278 & 82 \\
10 & 321 & 265 & 83 \\
11 & 279 & 213 & 76 \\
12 & 258 & 189 & 73 \\
13 & 208 & 133 & 64 \\
14 & 156 & 96 & 62 \\
15 & 109 & 53 & 49 \\
16 & 72 & 44 & 61 \\
17 & 64 & 21 & 33 \\
18 & 39 & 6 & 15 \\
& & &
\end{tabular}

Table 6. Pod-setting percentage on the two lowest and two highest fertile nodes

\begin{tabular}{lcccc}
\hline Node & $\begin{array}{c}\text { Number of } \\
\text { investigated } \\
\text { plants }\end{array}$ & $\begin{array}{c}\text { Number } \\
\text { of } \\
\text { flowers }\end{array}$ & $\begin{array}{c}\text { Number } \\
\text { of } \\
\text { pods }\end{array}$ & $\begin{array}{c}\text { Pod-setting } \\
\text { percentage }\end{array}$ \\
\hline First & 370 & 644 & 570 & 89 \\
Second & 370 & 561 & 511 & 91 \\
Next last & 370 & 492 & 343 & 70 \\
Last & 370 & 488 & 257 & 53
\end{tabular}

with the corresponding results for the peas, but the influence of the position on the plant seems to be much larger for the vetch than for the peas.

To throw further light upon this problem the author calculated the pod-setting percentages for the two flowers on the plants with the lowest position on the stem and the two flowers on the plants with the highest position on the stem; the results clearly agreed with those given in Table 5. Thus the pod-setting percentages for the two lowest flowers were 89 and 91 , respectively, when the corresponding percentages for the two highest pods were 70 and 53 (Table 6). The difference between slow» and "high" pods is much larger for the present vetch material than for the pea material studied earlier (17). 
Table 7 The pod length, pod breadth, number of ovules, number of seeds, seed weight per pod and their dependence on the position on the stem.

\begin{tabular}{lccccccc}
\hline $\begin{array}{c}\text { Position } \\
\text { of the } \\
\text { pod }\end{array}$ & $\begin{array}{c}\text { The length } \\
\text { of the } \\
\text { pods, } \\
\text { millimetres }\end{array}$ & $\begin{array}{c}\text { The breadth } \\
\text { of the } \\
\text { pods, } \\
\text { millimetres }\end{array}$ & $\begin{array}{c}\text { Number } \\
\text { of } \\
\text { ovules } \\
\text { per ovary }\end{array}$ & $\begin{array}{c}\text { Number } \\
\text { of fully } \\
\text { developed } \\
\text { seeds }\end{array}$ & $\begin{array}{c}\text { Number } \\
\text { of } \\
\text { defective } \\
\text { seeds }\end{array}$ & $\begin{array}{c}\text { Number } \\
\text { of } \\
\text { dead } \\
\text { ovules }\end{array}$ & $\begin{array}{c}\text { Seed } \\
\text { weight } \\
\text { milligrams } \\
\text { per pod }\end{array}$ \\
\hline First & 69 & 9.9 & 9.1 & 8.1 & 0.5 & 0.5 & 676 \\
Second & 68 & 9.8 & 9.1 & 8.0 & 1.1 & 0.0 & 641 \\
Third & 68 & 9.9 & 9.0 & 8.6 & 0.3 & 0.1 & 664 \\
Central & 68 & 9.7 & 8.7 & 8.0 & 0.6 & 0.1 & 570 \\
The next & 66 & 9.6 & 8.8 & 7.2 & 1.4 & 0.2 & 476 \\
Next last & 64 & 9.6 & 8.3 & 5.7 & 2.3 & 0.3 & 375 \\
Last & 61 & 9.5 & 8.1 & 5.3 & 2.7 & 0.1 & 319
\end{tabular}

\section{Seed-setting and its dependence on the position of the pod}

In Table 7 some results are given as to pods with different positions on the stem. From this table it appears that the length of the pods decreases with increasing height - measured in nodes - on the stem. The difference was considerable between the first and the last pods. It may be mentioned that the corresponding differences for the peas were small.

The number of ovules per ovary was considerably smaller for higher ovaries than for those with a lower position on the stem. The differences in number of ovules are of the same size as in the case of the length of the pods, relatively seen. The differences as to the number of ovules per ovary were considerably larger for the vetch material than for the investigated peas.

The number of fully developed seeds was on an average eight or more for both the three first and the central pods, but much smaller for the pods with the highest position on the stem. This seems to depend on the large number of defective seeds in the pods with a high position on the stem. The differences as to both these characters are much larger in the present material of vetches than in the earlier treated material of peas. As to the non-developed seeds the obtained results are not clear.

The seed weight per pod follows to a rather large extent the number of fully developed seeds, but the differences between the lowest and the highest pods are considerably larger for seed weight than for the number of seeds. The decreasing seed weight per pod with a higher position for the pod on the stem is very clear and striking and, relatively seen, much larger than the corresponding decrease found in the peas.

It seems also of interest to note how many pods are found on the plant. The present material contains only twenty plants, which is not considerable. The results are given in Table 8 . The length and breadth of the pods have not been influenced 
Table 8. The pod length, pod breadth, number of ovules, number of seeds, seed weight per pod and their dependence on the number of pods per plant.

\begin{tabular}{|c|c|c|c|c|c|c|c|c|c|}
\hline $\begin{array}{l}\text { Number } \\
\text { of pods } \\
\text { per plant }\end{array}$ & $\begin{array}{l}\text { Numbe } \\
\text { plants }\end{array}$ & $\begin{array}{l}\text { er of } \\
\text { pods }\end{array}$ & $\begin{array}{l}\text { The length } \\
\text { of the } \\
\text { pods, } \\
\text { millimetres }\end{array}$ & $\begin{array}{l}\text { The bre- } \\
\text { adth of the } \\
\text { pods, milli- } \\
\text { metres }\end{array}$ & $\begin{array}{c}\text { Number } \\
\text { of } \\
\text { ovules } \\
\text { per ovary }\end{array}$ & $\begin{array}{l}\text { Number } \\
\text { of fully } \\
\text { developed } \\
\text { seeds }\end{array}$ & $\begin{array}{l}\text { Number } \\
\text { of } \\
\text { defective } \\
\text { seeds }\end{array}$ & $\begin{array}{c}\text { Number } \\
\text { of } \\
\text { dead } \\
\text { ovules }\end{array}$ & $\begin{array}{c}\text { Seed } \\
\text { weigbt } \\
\text { milligrams } \\
\text { per pod }\end{array}$ \\
\hline $6-7$ & 6 & 37 & 65 & 9.6 & 8.7 & 7.4 & 1.1 & 0.2 & 581 \\
\hline $8-12$ & 10 & 95 & 67 & 9.6 & 8.8 & 7.4 & 1.3 & 0.1 & 555 \\
\hline $13-18$ & 4 & 58 & 65 & 9.7 & 8.5 & 6.8 & 1.4 & 0.3 & 447 \\
\hline On an ave & rage & 70 & 66 & 9.6 & 8.7 & 7.2 & 1.3 & 0.2 & 527 \\
\hline
\end{tabular}

by the number of pods per plant. A tendency to smaller number of ovules and fully developed seeds per ovary and pod, respectively, was found as well as an increasing number of defective seeds and dead ovules. The greatest interest, however, lies in the decreasing seed weight obtained per pod with increasing number of pods per plant. This weight was on an average in the material 527 milligrams, but 581 milligrams for plants with $6-7$ pods and 447 milligrams for plants with $13-18$ pods per plant. However, the seed weight per plant is much larger for plants with $13-18$ pods per plant than for plants with $6-7$ pods per plant. The numbers were as follows:

$\begin{array}{cc}\text { Number of pods per plant } & \text { Seed weight milligrams per plant } \\ 6-7 & 3583 \\ 8-12 & 5275 \\ 13-18 & 6488\end{array}$

The increasing frequency of defective and non-developed seeds is very clear if the figures per plant are examined. The figures are as follows:

\begin{tabular}{|c|c|c|c|c|}
\hline $\begin{array}{l}\text { Number of pods } \\
\text { per plant }\end{array}$ & $\begin{array}{l}\text { Number of } \\
\text { ovules per } \\
\text { plant }\end{array}$ & $\begin{array}{c}\text { Number of } \\
\text { fully developed } \\
\text { seeds per plant }\end{array}$ & $\begin{array}{c}\text { Number of } \\
\text { defective } \\
\text { seeds per plant }\end{array}$ & $\begin{array}{c}\text { Number of } \\
\text { dead ovules } \\
\text { per plant }\end{array}$ \\
\hline $6-7$ & 53.4 & 45.9 & 6.6 & 0.9 \\
\hline $8-12$ & 83.8 & 70.4 & 12.1 & 1.3 \\
\hline $13-18$ & 122.9 & 98.7 & 19.7 & 4.5 \\
\hline
\end{tabular}

From this it appears that when the number of fully developed seeds is increasing with about 115 per cent the number of defective seeds is increasing with about 200 per cent and the number of dead ovules with 400 per cent. Furthermore, from the figures given earlier it appears that the seed weight per plant increased with only 81 per cent. This small material indicates that there is a large influence on seedsetting and seed yield per plant of the number of pods per plant. 
In Table 9 a comparison is given between the seed-setting in pods that have been single on the node and pods that have been in pairs on the node.

The length of the pods was on an average the same for single pods as for pods in pairs. The breadth of the pods showed, however, a tendency to be larger for single pods than for pods in pairs.

Number of ovules per ovary showed only a small influence of the number of pods per node, which is in agreement with the results obtained in peas. The number of fully developed seeds showed a tendency to be larger for the pods found in pairs than for single pods. The number of defective seeds for pods in pairs were much larger than the corresponding values for the single pods in both the lowest and central position of the plants, but considerably smaller for the pods in the highest position on the plant, which depends on the large number of defective seeds in these pods found in pairs. The number of dead ovules has not been influenced on an average by the number of pods per node.

As for the peas in the material of vetches smaller seed weights per pod were found for single pods than for pods in pairs. The difference was, relatively seen, considerably larger for vetches than for peas.

\section{Discussion}

On the basis of the present study concerning seed-setting in vetches it can be said that very large resemblances have been found with the seed-setting in peas (17). This is naturally interesting but not in any way surprising. The largest difference in seed-setting between the used materials of peas and vetches is the much larger percentage of non-developed pods, which was about four times larger for the vetches. It must be recalled here that both in the case of peas and vetches crossings are largely

Table 9. Comparison between nodes with one and nodes with two pods in vetches.

\begin{tabular}{|c|c|c|c|c|c|c|c|c|}
\hline $\begin{array}{l}\text { Position } \\
\text { of the node } \\
\text { and pod } \\
\text { number }\end{array}$ & $\mathrm{n}$ & $\begin{array}{l}\text { The length, } \\
\text { of the } \\
\text { pods, } \\
\text { millimetres }\end{array}$ & $\begin{array}{l}\text { The breadth } \\
\text { of the } \\
\text { pods } \\
\text { millimetres }\end{array}$ & $\begin{array}{c}\text { Number } \\
\text { of } \\
\text { ovules } \\
\text { per ovary }\end{array}$ & $\begin{array}{l}\text { Number } \\
\text { of fully } \\
\text { developed } \\
\text { seeds }\end{array}$ & $\begin{array}{l}\text { Number } \\
\text { of } \\
\text { defective } \\
\text { seeds }\end{array}$ & $\begin{array}{l}\text { Number } \\
\text { of dead } \\
\text { ovules }\end{array}$ & $\begin{array}{c}\text { Seed } \\
\text { weight } \\
\text { milligrams } \\
\text { per pod }\end{array}$ \\
\hline \multicolumn{9}{|c|}{ One pod per node } \\
\hline Lowest & 11 & 67 & 9.9 & 8.7 & 7.8 & 0.9 & 一 & 617 \\
\hline Central & 25 & 68 & 9.8 & 8.9 & 6.6 & 1.9 & 0.4 & 485 \\
\hline Highest & 11 & 63 & 9.7 & 8.1 & 6.7 & 1.3 & 0.1 & 351 \\
\hline Mean & & 66 & 9.8 & 8.7 & 7.0 & 1.5 & 0.2 & 484 \\
\hline \multicolumn{9}{|c|}{ Two pods per node } \\
\hline Lowest & 40 & 69 & 9.8 & 9.2 & 8.3 & 0.6 & 0.3 & 661 \\
\hline Central & 52 & 66 & 9.6 & 8.7 & 7.7 & 0.8 & 0.2 & 554 \\
\hline Highest & 40 & 65 & 9.5 & 8.5 & 6.1 & 2.2 & 0.2 & 442 \\
\hline Mean & & 66 & 9.6 & 8.8 & 7.4 & 1.2 & 0.2 & 552 \\
\hline
\end{tabular}


used; these have been partly crosses between luxuriant fodder types and seed types. This indicates that the pod-setting in vetches is poorer under the conditions of Southern Scania than in peas under the same conditions, which to some extent agrees with the practical experiences of the seed cultivation of vetch in this province.

The defectiveness in pod-setting is extremely large at the top of the plant. The same is also true of the seed-setting and seed weight, namely, large differences between the lower and higher of the fertile nodes. These differences are in the opinion of the present author entirely or at least largely due to the time differences in development for the different flowers and pods and furthermore to the differences in length of the conducting tissues to the flowers and pods in agreement with earlier published investigations undertaken by the present author $(16,17)$. The reason that the influence of the position on the stem of the flowers and pods, respectively is larger for vetches than for peas is possibly the fact that the pod-bearing part of the plant - measured in nodes - has been larger in the used material of vetches than in the investigated pea material, but this is not sufficient to explain the diffeiences. One more important factor seems to be the large time differences between development of the pods with low and high positions on the stem. Furthermore, other differences between both species must naturally be considered to exert influence. These characters can be both of anatomical and physiological nature. Here we shall mention only one, namely, the differences in diameter of the stem. Further it can be pointed out that when the differences in diameter and circumference of the stem are a little more than twice as large, on an average, for the peas than for the vetches the surface of the intersection is more than four times as large.

The practical consequences of the defectiveness in pod- and seed-setting are naturally large. Partly the seed yield is smaller when the pod- and seed-setting are defective, and partly the yield is qualitatively not as good as when all the seeds are fully developed, because the not fully developed seeds are very likely not germinative. Furthermore, at threshing, cleaning and assorting, these seeds disappear or decrease the quality of the seed for marketing or sowing purposes. It must further be considered as possible that the nutritional value of the not fully developed seeds is less than that of the same weight of fully developed seeds. Therefore the economic consequences of defective pod- and seed-setting must be considered to be rather farreaching.

The early varieties of vetches probably do not show such large differences in seed-setting at different heights on the stem, but these varieties have in practical plant husbandry shown themselves to give much smaller green matter yields. Because the defectiveness in pod- and seed-setting is largely depending on the rhythm of development, physiological and time factors and the influence of environment, it must be considered to be a difficult but important aim for plant breeding to breed high yielding varieties of vetch for the green matter production, which have a good seed-setting too. The plant breeding work as regards the seed vetch type must largely be built on an analysis of the pod- and seed-setting of the material. 
The differences between different genetical materials as to the investigated characters have been large.

The percentage of non-developed and fallen pods was on an average 21 and varied between 2 and 64 . The mean percentage of non-developed and fallen pods was 5.5 and varied between 0 and 16 in the peas.

The percentage of fully developed seeds was much smaller for the first ovule than for the central ones. The percentage of fully developed seeds was 70 in one material and the percentage of developed ovules (fully developed + defective seeds) in another material was 88.3. The corresponding percentages for the central seeds were 84 and 98.1 , respectively, and for the last (outermost) seeds in the pods 82 and 91.1 , respectively.

The frequency of pods with only fully developed seeds was smaller for pods with a small number of seeds (ovules) per pod than for pods with a high number.

The percentage of dead ovules was much higher for ovaries with a small number of ovules than for ovaries with a high number of ovules per ovary. The percentage of fully developed seeds showed a tendency to be higher for ovaries containing a large number of ovules than for ovaries containing a small number of ovules.

Pod-setting percentage was much higher for the flowers with a low position (early) on the plant than for the flowers with a high position (late) on the stem. The difference was much larger than the corresponding one for the pea material.

The length and breadth of the pods showed a tendency to be larger for low pods than for pods with a high position on the stem.

Number of ovules per ovary showed a tendency to be higher for the lowest flowers than for the highest flowers. The difference was however much larger as to the fully developed seeds because the number of defective seeds was much higher for pods with a high position on the stem.

Seed weight per pod was much larger for pods with a low position on the stem (early) than for pods with a high position on the stem (late). The mean seed weight showed about the same variation.

Seed weight per pod for plants with a large number of pods per plant was smaller than for plants with a small number of pods per plant. The mean seed weight showed about the same variation.

The number of fully developed seeds was somewhat larger for pods from nodes with two pods per node than for pods from nodes with only one pod per node.

Seed weight per pod showed a tendency to be larger for pods from nodes with two pods per node than for pods from nodes with only one pod.

Comparisons are in many cases made between vetches and peas, and, further, are the practical consequences of the obtained results discussed.

\section{REFERENCES}

(1) Broekema, C. 1933. Oogstanalytische vergelijking van tarwerassen. Landbouwk. Tijdschr. 45: 921 -937 . 
(2) Clark, G. H. \& Malte, M. O. 1923. Fodder and pasture plants. 143 pp. Ottawa.

(3) Coutrnho, L. A. 1940. Raças cariológicas na V. sativa L. (With Engl. summary). Agron. Lusitana 2: $379-403$,

(4) Fernald, M. L. 1950. Gray's manual of botany. 1632 pp. New York.

(5) FinneY, D. J. 1953. An introduction to statistical science in agriculture. 179 pp. Copenhagen.

(6) Fisher, R. A. \& Yates, F. 1953. Statistical tables for biological agricultural and medical research. 126 pp. Edinburgh.

(7) Foury, A. 1954. Les légumineuses fourragères au Maroc. Les Cahiers de la Rech. Agron. 5: 289656.

(8) Hegr, G. 1925. Illustrierte Flora von Mittel-Europa. IV. Band 3: 1113-1748.

(9) Heuser, W. 1928. Die Ertragsanalyse von Getreidezüchtungen. Pflanzenbau 4: $353-357$.

(10) Hutonen, I. 1933. Suomen kasvio. 773 pp. Helsinki.

(11) Hännınen, P. 1949. Ennakkotietoja herneen ja virnan säilyvyydestä seosviljoissa Suomessa. (With Engl. summary). Maatal. tiet. aikak. 10:29-33.

(12) $\rightarrow$ 1956. Herneen ja virnan viljelymahdollisuuksista kaurakasvustoissa Suomessa. (With Engl. summary). Valt. maatal.koetoim. julk. N:o 153: 1-131.

(13) Juhlin-Dannfelt, H. 1901. Handbok i Jordbrukslära. Lantbrukets bok II. 613 pp. Stockholm.

(14) Lechner, L. 1956. Wicken- (Vicia-) Arten. Handb. der Pflanzenzücht. IV: $54-$

(15) Lindman, C. A. M. 1926. Svensk fanerogamflora. 644 pp. Stockholm.

(16) Manner, R. 1956. Studies on seed-setting and seed yield in oil flax. Diss. 139 pp. Hammenhög.

(17) Manner, R. 1958. Studies on seed-setting in leguminous plants. I. Peas. Maatal.tiet. aikak. 30: 143-157.

(18) Muratova, V. S. 1926. Materials to the determination of the most important forage vetches. (Russ. with Engl. summary). Bull. of Appl. Botany and Plant-breeding 16: 99-150.

(19) Mưller, F. 1939. Wicken und Pferdebohne. Handb. der Pflanzenzücht. III: $64-86$.

(20) Sauli, J. O. 1945. Peltokasvinviljelys. Maamiehen käsikirja 103-241. Helsinki.

(21) Sveriges Utsädesförening 1936. Sveriges Utsäfesförening 1886-1936. En minnesskrift. Sver. utsädesförenings tidskr. 46: $153-394$.

(22) Sveshnikova, I. N. 1927. Karyological studies on Vicia. (Russ. with Engl. summary). Bull. of Appl. Botany and Plant-breeding 17 (3): $37-72$.

(23) Tupikova, A. I. 1926. Botanico - Agronomical investigations of annual vetches. (Russ. with Engl. summary). Bull. of Appl. Botany and Plant-breeding 16: 151-246.

(24) VAlle, O. 1946. Palkokasvien merkitys rehuviljan tuotannossa. Maatal. ja koetoim. I: 115 -134.

(25) Wellensiek, S. J. 1941. Oogstanalyse I: oriëntatie bij erwten. (With Engl. summary). Meded. Landbouwhocgeschool te Wageningen 45: 1-29.

(26) ÅKerberg, E. 1951. Baljväxter. Svensk växtförädling I: 233-274.

\author{
S E L OS T U S :
}

\title{
PALKOKASVIEN SIEMENTEN MUODOSTUMISESTA. II. VIRNA
}

\section{Rolf MANNER}

\section{Gullakerin kasvinjalostuslaitos, Hammenhög, Ruotsi}

Vuosina 1956-57 on tekijä Gullăkerin kasvinjalostuslaitoksella suorittanut joukon virnan siementen muodostumista koskevia tutkimuksia. Kasviaineistona on käytetty eräiden risteytyspopulaatioiden $\mathrm{F}_{2}$-sukupolvea ja näiden risteytyspopulaatioiden vanhempia.

Tutkimustulokset ovat suurin piirtein yhtäpitävät vastaavien herneellä saatujen tulosten kanssa. Eroavaisuuksista mainittakoon, että sikiäimistä keskimäärin 21 prosenttia ei kehittynyt ollenkaan tai kuoli. Tämå prosenttimăäră oli lähes neljä kertaa suurempi kuin vastaava luku herneellä. Ylipäänsä olivat erot palkojen ja siementen muodostumisen välillä kasvien latvoissa ja varren muissa osissa paljon suuremmat virnalla kuin herneellä. Tämä koskee myös palkojen keskimääräistä siementen painoa. 